\title{
TIPOVI GLAGOLSKIH SITUACIJA U KOMPLEMENTU POČETNIH FAZNIH GLAGOLA U SRPSKOM JEZIKU ${ }^{1}$
}

\begin{abstract}
SAŽETAK
U ovom radu se govori o složenom predikatu, tj. o vrsti predikacije u okviru koje je uloga faznog glagola da modifikuje značenje leksičkog glagola u pogledu faznosti. Drugim rečima, proučavaju se semantički nepotpuni glagoli (fazni glagoli) i drugi punoznačni glagoli koji se nalaze u ulozi sintaksičkog i semantičkog komplementa. U obzir se uzima i uticaj faznih glagola na glagol u komplementaciji kao i kako pomenuti uticaj varira u zavisnosti od aspektualnih karakteristika glagola unutar komplementa. Istraživanje ima za cilj da odredi tipove glagolskih situacija koji se nalaze u dopuni, a analizom korpusa ustanovljeno je da se na datoj poziciji nalaze isključivo stanja $\mathrm{i}$ aktivnosti.
\end{abstract}

KLJUČNE REČI: fazni glagoli, glagolski vid, tip glagolske situacije, akcionsart, teličnost, promena tipa glagolske situacije, srpski jezik.

\section{Uvod}

U srpskom jeziku fazni glagoli svrstavaju se u grupu glagola nepotpunog značenja važnih za formiranje rečenica i glagolskih konstrukcija uopšte (Станојчић и Поповић 1995: 247-248). Oni su leksički nesamostalni glagoli koje karakteriše zavisnost od druge reči, najčešće drugog punoznačnog glagola s kojim fazni glagol formira celinu. S obzirom na to da predstavljaju sintaksički nepotpune jedinice, oni pripadaju klasi semikopulativnih glagola (Antonić 2000: 95). Kako navedeni termin ukazuje, fazni glagoli označavaju različite etape ili faze u trajanju određene radnje:

- počinjanje, nastajanje, pojavljivanje, rađanje, stvaranje izvesne radnje;

${ }^{1}$ Ovaj rad predstavlja deo doktorske disertacije pod nazivom Semantičko-sintaksički međuodnos faznog glagola $i$ komplementa u engleskom i srpskom jeziku - kontrastivni pristup koja je odbranjena 29. septembra 2020. na Filozofskom fakultetu u Novom Sadu. 
- trajanje, nastavljanje, produžavanje određene radnje;

- završetak, prekidanje, zaustavljanje, prestanak, kraj u trajanju neke radnje (Крстић 2016: 142-144).

\section{Teorijski okvir}

Upotrebom faznog glagola u rečenici nastaje konstrukcija koja se zove složeni predikat. Takva konstrukcija je sastavljena od faznog dela predikata i dopunskog dela predikata. Fazni deo predikata čini fazni glagol u ličnom (finitnom) obliku, a dopunski deo kod složenog glagolskog predikata čini glagol punog značenja upotrebljen ili $\mathrm{u}$ obliku infinitiva ili $\mathrm{u}$ obliku prezenta (kongruentnog sa subjektom) s veznikom $d a$ (Станојчић и Поповић 1995: 248). U ovom radu polazne strukture su početni fazni glagoli u srpskom jeziku (početi, počinjati) sa dopunskom klauzom, ${ }^{2}$ a to je drugi punoznačni glagol s kojim fazni glagol čini gramatičku i semantičku celinu (Ружић 2006: 136-137). Drugi punoznačni glagol nalazi se u obliku infinitiva ili u kombinaciji s klauzom $d a+$ prezent. Pod terminom glagolski komplement podrazumevaće se konstituentska struktura koja kako sintaksički tako i značenjski realizuje celinu sa svojim upravnim glagolskim elementom. Ukoliko bi se ovakva gradivna jedinica uklonila ili pomerila nastupilo bi narušavanje sintaksičkog integriteta iskaza, te bi se potpuno izmenio ili obesmislio prvobitni sadržaj propozicije ${ }^{3}$ (Каравесовић 2015: 73). Glagol u ličnom glagolskom obliku upućuje na početnu fazu komplementskog glagolskog sadržaja (Novakov 2005: 100). U ovom radu proučava se tip situacije glagola u komplementu.

S obzirom na to da se u okviru ovih konstrukcija javljaju dva glagola, pa s tim u vezi i dva tipa akcionsarta, celu konstrukciju ne bi trebalo svrstavati u samo jedan tip glagolske situacije, već je potrebno preciznije utvrditi kom tipu glagolske situacije pripada upravni glagol u ličnom glagolskom obliku, kao i glagol u dopuni. Akcionsart kao pozajmljenica iz nemačkog jezika, odnosi se na unutrašnju temporalnu strukturu glagolskog događaja i predstavlja leksički aspekt koji se bavi značenjima glagola i semantičkim kategorijama glagola (Rothstein 2004: 1). U

\footnotetext{
${ }^{2}$ Za komplement koji ima strukturu rečenice upotrebljava se i termin komplementizator, kao i termini - dopunska ili komplementna klauza (Ружић 2006).

${ }^{3}$ Pod terminom propozicije podrazumevaće se objedinjeni značenjski sadržaj kog u formi jedinstvenog predikata čine upravna i dopunska struktura (Мишовић-Луковић 2006: 35).
} 
postojećoj literaturi koriste se različiti termini poput „tipa glagolske situacije”4, „situacionog aspekta” (Smith 1995) ili „leksičkog aspekta” (Comrie 1976). B. Komri navodi da je tu u pitanju inherentno aspektualno značenje, dok R. Binik tvrdi da ovaj termin predstavlja unutrašnje značenje koje prenosi glagol, a ne gramatička struktura (Binnick 1991: 148). Tip glagolske situacije definisan je uz pomoć četiri temporalna obrasca (stanja, aktivnost, ostvarenje, dostignuće; engleski termini: state, activity, accomplishment, achievement) i tri distinktivna obeležja (stativnost, trajanje i teličnost). U srpskom jeziku značajno je obeležje cilj, pa se pomoću njega ostvaruje veza s glagolskim vidom jer je kontrast između imperfektivnosti i perfektivnosti baziran i na osnovu semantičkog obeležja [cilj]. Glagolske lekseme već u leksikonu označavaju ne samo tip glagolske situacije već i glagolski vid (Novakov 2005: 132). U ovom istraživanju primenjuje se početna Vendlerova klasifikacija glagola i glagolskih izraza budući da je opšteprihvaćena u savremenim lingvističkim proučavanjima. Z. Vendler (1967) je autor jedne od najznačajnijih studija o leksičkom aspektu, te se veliki broj kasnijih istraživanja zasniva na njegovoj podeli:
a) Stanja: znati, voleti;
b) Aktivnosti: trčati, pevati;
c) Ostvarenja: nacrtati krug, napisati pismo;
d) Dostignuća: pobediti, pronaći, stići.

Tabela 1: Podela tipova glagolskih situacija prema Z. Vendleru

\begin{tabular}{lccc}
\hline Klasa glagola & Stativnost & Trajanje & Teličnost \\
\hline Stanja & + & + & - \\
Aktivnosti & - & + & - \\
Ostvarenja & - & + & + \\
Dostignuća & - & - & + \\
\hline
\end{tabular}

\footnotetext{
${ }^{4}$ Pod glagolskom situacijom podrazumeva se radnja, stanje, zbivanje, proces, odnosno, sve ono što se u anglističkoj tradiciji objedinjuje pod generičkim terminom eventualnost (engleski termin: eventuality). U ovom radu termin eventualnost vezuje se za pojam koji je u srbističkoj literaturi označen kao tip glagolske situacije (npr. Novakov 2005). V. Stanojević i T. Ašić (2006: 26) definišu eventualnost kao pojam koji je širi od događaja s obzirom na to da događaji po pravilu podrazumevaju promenu, dok to nije slučaj $\mathrm{s}$ eventualnošću. Kao i stanja, i događaji predstavljaju podtipove eventualnosti.
} 
Vendler je prikazao na koji način se glagoli u ovim klasama razlikuju po karakteristikama stativnosti, trajanja i teličnosti. Događaj je stativan ako ne uključuje promenu tokom vremena, trajan ako podrazumeva vremensko trajanje i teličan ukoliko ima krajnju tačku. Teličnost će se u ovom radu tretirati kao usmerenost ka završnoj tački, tj. određenom rezultatu. Polazi se od koncepta teličnosti po kom je situacija telična ukoliko teži cilju i ukoliko u njenoj strukturi postoji kulminacija dok se ne stigne do krajnje tačke (Novakov 2016: 404). Glagolsko obeležje cilj ili teličnost definiše se kao semantičko obeležje glagola koje unosi prisustvo cilja, tj. težnju da glagolska radnja bude na neki način usmerena, svršena i/ili kompletna (Milivojević 2007: 398). Teličnost označava da glagolska situacija ima segmente, odnosno da ima strukturu, a postojanje i dostizanje cilja definiše situaciju kao teličnu bez obzira na to koliko ta situacija traje (Lazović 2012: 24).

U proučavanjima glagolskog sistema u srpskom jeziku teličnoj komponenti glagolskog značenja nije posvećena adekvatna pažnja, te se nisu ni razmatrale jednakosti između teličnosti i perfektivnosti, odnosno ateličnosti i imperfektivnosti. Novakov tvrdi da je teličnost obeležje koje je usko vezano za glagolski vid i smatra da su atelični glagoli po pravilu imperfektivni, dok su telični glagoli perfektivni jer naznačavaju da je postojeći cilj dostignut (2009: 47-48). Sa ovim mišljenjem slažu se i Stanojević i Ašić (2006: 260). Oni smatraju da je teličnost povezana sa svršenim glagolskim vidom u srpskom jeziku. Pored toga, da bi označili ostvarenje kao tip glagolske situacije, oni koriste izraz trajno svršeni događaj, dok dostignuće tretiraju kao trenutno svršeni događaj. U atelične glagolske situacije ubrajaju stanja i aktivnosti i tvrde da se u srpskom jeziku ove eventualnosti ne mogu povezati s nesvršenim glagolima. Stanja i aktivnosti, pored ateličnosti, karakteriše homogenost i nedinamičnost. Homogenost podrazumeva odvijanje radnje koja se sastoji od istih segmenata, te nema prirodnu ivičnu tačku, već samo teče u vremenu. Trenutnosvršene i trajnosvršene događaje, osim teličnosti, odlikuje dinamičnost $\mathrm{i}$ heterogenost. Teličnost $\mathrm{i}$ heterogenost podrazumevaju postojanje prirodne krajnje tačke koja je i ograničenje nakon kojeg eventualnost prestaje da se odvija jer nastaje određena promena i situacija u tom slučaju ne može da se nastavi (Станојевић и Ашић 2006: 27-29).

Jedan od najčešće korišćenih testova za utvrđivanje glagolskog vida jeste onaj u kom se koriste konstrukcije s faznim glagolima koje kao dopunski deo predikata 
zahtevaju glagol imperfektivnog vida (Mrazović i Vukadinović 2009: 83) (npr. počeo je da radi, počeo je raditi; ali ne $\mathrm{i}$ *počeo je da uradi, *počeo je uraditi ${ }^{5}$ ).

1. Ivan je рос̌еo da prepisuje / *prepiše zadatak. (Станојчић и Поповић 1995: 247-248).

Svi fazni glagoli kao dopunu imaju isključivo imperfektivne (nesvršene) samostalne glagole:

2. Počeo je / nastavio je / prestao je da radi.

ali ne i:

3. Počeo je / nastavio je / prestao je da *uradi (Mrazović i Vukadinović 2009: 195-196).

\section{Cilj istraživanja}

Cilj je odrediti sve tipove glagolskih situacija koji se mogu naći u okviru komplementa faznog glagola. Polazi se od pretpostavke da situaciju u dopuni odlikuje trajanje da bi fazni glagol mogao da uputi na određenu etapu takvog događaja, tj. na određeni vremenski segment događaja označenog glagolom $u$ komplementaciji. U vezi s prethodno navedenim ciljem, potrebno je analizirati učestalost tipa glagolskih situacija u okviru komplementacije faznog glagola. Analiza se oslanja na podelu glagolskih situacija koja se pominje u literaturi kod Vendlera (1967). Pored toga, utvrdiće se najčešći oblik glagolske situacije u komplementu.

\section{Metodologija rada}

U prvoj metodološkoj fazi istraživanja ispitano je postojanje faznih glagola početi i počinjati u srpskom jeziku, a zatim su utvrđena njihova značenja $\mathrm{u}$ jednojezičnim rečnicima. Konsultovana su dva rečnika i to:

${ }^{5}$ U daljem radu ova oznaka ${ }^{*}$ ) upućivaće na gramatički neadekvatno oformljenu konstrukciju. 
1. REČNIK SRPSKOHRVATSKOGA KNJIŽEVNOG JEZIKA (skraćeno: RSKJ)

uređivački odbor: Mihailo Stevanović i dr., drugo fototipsko izdanje u 6 knjiga. 1990. Novi Sad.

2. REČNIK SRPSKOGA JEZIKA (skraćeno: RSJ)

izradili Milica Vujanić i dr., redigovao i uredio Miroslav Nikolić. 2007. Novi Sad.

Osnovno značenje faznog glagola početi odnosi se na označavanje početne faze određene situacije, tj. glagolske radnje. U dvovalentnoj upotrebi ovoga glagola osim imenske reči u obliku akuzativa bez predloga ili instrumentala s predlogom $s(a)$ istupa imperfektivni glagol u obliku infinitiva ili konstrukcija $d a+$ prezent $\mathrm{u}$ funkciji druge valentnosti.

U Rečniku srpskohrvatskoga književnog jezika glagol početi definisan je na sledeći način:

- pòčēti, pöčnēm svrš.

1. a. načiniti, napraviti početak, započeti:

4. Počne nabrajati Švejku čitav niz raznih zločina, počevši od veleizdaje.

b. započeti što novo, drugo:

5. Odjednom čitač poče glasom padati.

6. San me je počeo hvatati. (RSKJ, 828)

Da bi se sistematično ispitalo, a potom i opisalo ponašanje faznih glagola, trebalo bi odrediti odgovarajući kontekst koji će ispuniti potrebe analize jezika. U tom smislu, biće ponuđen i osvrt na opis konteksta koji navodi T. Prćić (1997: 28) a koji predstavlja optimalan kontekst. To je kontekst koji daje dovoljno podataka što je u najvećem broju slučajeva rečenica, kao deo teksta. Prema tome, u ovome istraživanju termin ,jezički kontekst” označavaće ovako definisan optimalni kontekst. Ova definicija predstavlja vrlo značajan metodološki pojam analize budući da služi kao smernica za sledeću fazu istraživanja koja podrazumeva proveru konstrukcija s faznim glagolima na rečeničnom korpusu primera.

Odabrani korpus se sastoji od tekstualne građe iz dva američka romana Stivena Kinga, ${ }^{6}$ koji pripadaju žanru misterije i horora:

\footnotetext{
${ }^{6} \mathrm{~S}$ obzirom na to da ovaj rad predstavlja samo jedan deo doktorske disertacije u kojoj se kontrastira engleski i srpski jezik u sintaksičko-semantičkim okvirima, rečenični korpus je
} 
1. Stiven King (2010). Vreća kostiju. Beograd: Vulkan izdavaštvo. (430 strana)

prevodilac: Ana Grbić

2. Stiven King (2003). Crna kuća. Beograd: Editor. (529 strana)

prevodilac: Aleksandar Marković

Ukupno je pretraženo 959 strana teksta i izdvojeno 292 primera rečenica.

Da bi se omogućila lakša pratljivost teksta, u daljem radu koristiće se skraćenice zasnovane na naslovima književnih dela:

- VK (Vreća kostiju)

- CK (Crna kuća)

Tabela 2: Tabelarni pregled korpusa na srpskom jeziku

\begin{tabular}{lll} 
Naziv književnog dela & Broj strana & Broj primera \\
\hline Vré́a kostiju & 430 & 187 \\
\hline Crna kuća & 529 & 105 \\
\hline & Ukupan broj strana: 959 & Ukupan broj primera: 292
\end{tabular}

\section{Analiza i diskusija}

U okviru ovog istraživanja sprovodi se kvalitativna i kvantitativna analiza radi temeljnije obrade tematike. Kvantitativna analiza obuhvata brojčane i statističke podatke kao što su broj rečeničnih primera, frekventnost pojedinačnih glagola i konstrukcija itd. Pod kvantitativnom obradom podrazumeva se utvrđivanje broja ekscerpiranih primera iz korpusa, a nakon dobijenih kvantitativnih podataka mogu se utvrditi određene zakonitosti ili tendencije vezane za proučavane pojave. Građa će se zatim podvrgnuti kvalitativnoj analizi baziranoj na teorijskim postavkama predočenim u pregledu vladajućih stavova iz literature i tako će se utvrditi strukturni i semantički stepen poklapanja proučavanih jezičkih realizacija. Kvalitativna analiza pruža dublji uvid u građu i sistematizaciju formalnih teorijskih zaključaka istraživanja.

primarno obuhvatao strukture $\mathrm{u}$ engleskom jeziku, a potom i prevodne ekvivalente $\mathrm{u}$ srpskom jeziku, te se iz tog razloga u ovoj analizi nalazi preveden tekst umesto književnog dela napisanog savremenim srpskim jezikom. 
Predmet analize su tipovi glagolskih situacija na poziciji dopunskog dela predikata početnih faznih glagola. Ispitani su utemeljeni stavovi iz literature koji se odnose na obavezno prisustvo imperfektivnih glagola u komplementu faznih glagola i empirijski je potvrđena njihova istinitost. U daljoj analizi korpusa utvrdiće se tip situacije glagola u komplementu imajući u vidu dosadašnja tumačenja relevantnih lingvista koji zaključuju da se aktivnosti i stanja javljaju u imperfektivnom, a ostvarenja i dostignuća u perfektivnom vidu u srpskom jeziku (Novakov 2005: 82-83). S obzirom na to da je perfektivnost u srpskom jeziku povezana $\mathrm{s}$ teličnošću, a imperfektivnost $\mathrm{s}$ ateličnošću, ipak se navodi da $\mathrm{u}$ srpskom jeziku može da postoji kombinacija teličnog i imperfektivnog (Novakov 2009: 49). U tom slučaju, uz imperfektivni glagol cilj je sintaksički označen direktnim objektom, kao u primeru pisati pismo. Ipak, ne postoji naznaka o dostizanju cilja jer je glagol pisati imperfektivan. $\mathrm{S}$ tim u vezi, trebalo bi ispitati kako se uticaj objekta reflektuje na tumačenje tipa situacije glagola u dopuni. Ukoliko se uporedi situacija s engleskim jezikom gde glagolski dodaci imaju presudan značaj u utvrđivanju teličnosti, pa potom i tipa glagolske situacije, $u$ obzir treba uzeti i brojivost objekta. Ukoliko su dodaci brojivi, glagolskim sintagmama se označava telični događaj, a ukoliko nisu brojivi, označava se ateličnost (Smith 1997: 31). U srpskom jeziku, uticaj objekta na tip glagolske situacije ne postoji budući da je akcionsart određen već na leksičkom nivou, a glagolski vid se iskazuje formom glagola. Ispitivanje teličnosti može se obaviti uz pomoć dijagnostičkih testova koji podrazumevaju upotrebu mernih fraza (tokom) $X$ vremena i za $X$ vremena. Prvi test s priloškim izrazom može da se primeni na stanja i aktivnosti, a drugi na ostvarenja i dostignuća (Novakov 2005: 27-30).

7.

a) Ona ponovo počinje da peva refren Tajeve uspavanke, i on to ne može da podnese. $(\mathrm{CK}, 116)$

b) Peva refren Tajeve uspavanke pet minuta / *za pet minuta.

c) Peva refrene Tajeve uspavanke pet minuta / *za pet minuta.

8.

a) Spidi ga na trenutak nemo posmatra, pa umesto odgovora ponovo počinje da svira onu živu melodiju. (CK, 165)

b) Svira onu živu melodiju pet minuta / *za pet minuta.

c) Svira one žive melodije pet minuta / *za pet minuta. 
9.

a) Seo sam pred pisaću mašinu, napravio par proreda i počeo sebi da pišem podsetnik za sutra. Kakva kisela skalamerija je taj telefon. (VK, 192)

b) Pišem podsetnik za sutra pet minuta / *za pet minuta.

c) Pišem podsetnike za sutra pet minuta / *za pet minuta.

10.

a) „Hteli ste da kažete da ste morali da uključite kasetofon”, rekla je i tada sam se setio kako je voda promenila boju kada me je dobro zakucala $\mathrm{u}$ potiljak. Od drečavo narandžastog do tamno crvenog. A onda sam počeo da pijem jezero. (VK, 339)

b) Pijem jezero pet minuta /*za pet minuta.

c) Pijem jezera pet minuta /*za pet minuta.

$\mathrm{U}$ navedenim primerima glagoli u komplementu su aktivnosti, a objekat $\mathrm{u}$ dopuni ne menja aktivnost u ostvarenje.

U kombinaciji s glagolima stvaranja kakvi su, na primer, glagoli šiti, graditi, pisati, zidati javlja se objekat koji nastaje kao produkt. Radnja označena glagolom odvija se do tačke stvaranja objekta. Uz fazne glagole ne javlja se perfektivni glagol koji bi ukazao na rezultat radnje, već imperfektivni oblik koji podrazumeva početak procesa:

11. Sutradan ću početi da gradim neki život ovde ... da pokušam, barem. $(\mathrm{VK}, 98)$

Poznato je da predlozi i priloške odredbe mogu da specifikuju cilj budući da označavaju određenu dužinu. Ukoliko je putanja ograničena, događaj je teličan, a ako predlog ne ukazuje na postojanje ograničenja, događaj je ateličan. U korpusu se javlja nekoliko primera u kojima predlog označava pravac, te situacija u dopuni predstavlja aktivnost:

12.

a) Pre nego što će tri policajca i Sojer početi da šuškaju prema ulazu u lokal, Vendel izviruje, diže fotoaparat i snima neznanca. (CK, 214)

b) Šuškaju prema ulazu u lokal pet minuta / * za pet minuta. 
c) Ako neko prestane da šuška prema ulazu, on jeste šuškao prema ulazu.

13.

a) Osećaj je tada počeo da se pomera prema zadnjem delu glave i slabi. (CK, 395)

b) Pomera se prema zadnjem delu glave pet minuta / *za pet minuta.

14.

a) Počeo sam da plivam ka obali, do mesta na kome bih mogao da ustanem. Rodžet Vitmor je počela da ispaljuje kamenice istog trenutka, prvo je bacala kamenje koje je rukom pridržavala na grudima, a onda one koje je nagomilala u Devorovo krilo. (VK, 243)

b) Koliko dugo si plivao ka obali?

c) Plivao sam ka obali dva sata / *za dva sata.

15.

a) Počeo sam da pljuskam u tom pravcu rukama i nogama teškim kao olovo. (VK, 245)

b) Pljuskam u tom pravcu dva sata / *za dva sata.

U ovim rečenicama izražena je usmerenost objekta prema cilju, a treba napomenuti da ne postoji informacija o tome da li se cilj dostiže.

Određena grupa predikata izražava stepen, te označava povećanje ili umanjenje nekog svojstva. S obzirom na to da oni upućuju na promene koje su postepene, dati stepen ili cilj ne mora biti dostignut jer kod njih i ne postoji krajnja tačka budući da takvi procesi nemaju apsolutno homogenu strukturu. Ukoliko se primene testovi za ispitivanje tipa situacije, dolazi se do zaključka da su predikati za izražavanje stepena u srpskom jeziku zapravo stanja jer traju nezavisno od želje, volje i uticaja subjekta:

16.

a) Pantalone počinju da mu se suše, i oseća se neobično smireno. (CK, 179)

b) Koliko dugo mu se pantalone suše?

c) Pantalone mu se suše dva sata / *za dva sata. 
17.

a) $\mathrm{U}$ jednom momentu se videlo samo nebo koje tamni (boja indiga je počela da se širi sa ivica kao ubrizgano mastilo), a u sledećem je tu svetlucala Venera, sjajna i nepomična. (VK, 71)

b) Koliko dugo se boja indiga širi?

18.

a) Pritisak u grudima je počeo da se smanjuje, ali je bol bio jasan kao dan. (VK, 235)

b) Koliko dugo se pritisak smanjuje?

19.

a) Nagnuo sam se i poljubio je u obraz koji je konačno počeo da se hladi. (VK, 372)

b) Obraz se hladi pet minuta / *za pet minuta.

Glagoli perfektivnog vida, kao što su doći, ući i stići predstavljaju dostignuća prema tipu situacije budući da su trenutne radnje. U značenju ovih glagola postoji krajnja tačka koja ukazuje na izvršenost glagolske radnje. U aspektualnim konstrukcijama s početnim faznim glagolima ove glagolske lekseme pojavljuju se isključivo u svom imperfektivnom obliku i označavaju aktivnosti:

20.

a) „Provešćemo razumno samačko veče pre nego što sinovi i kćeri istočnog Maldena počnu da stižu. Sipam ti piće čim spustim slušalicu." (VK, 44)

b) Otišao je do kola, počeo da ulazi unutra, a onda zastao, prebacivši jednu dlakavu ruku preko otvorenih vrata. (VK, 136)

c) Konačno je počela da dolazi sebi. „Žao mi je. Nisam tako plakala stvarno plakala - otkad je Lens umro.” (VK, 265)

Utvrđeno je da prefiksacija i sufiksacija u srpskom jeziku utiču na tip situacije. Prefiksi i sufiksi predstavljaju glagolsku situaciju kao imperfektivnu bez obzira na značenje prefiksa koje unosi u glagolsku semantiku, te se smatraju aktivnostima koje traju ili koje označavaju ponavljanje situacije. Zapravo, sufiksacija glagola s prefiksom utiče na promenu tipa situacije i tim putem gradi aktivnosti: 
21.

a) Ima nečeg čudno utešnog u razgovoru sa advokatom čiji je taksimetar počeo da otkucava; kada pređete magičnu tačku u kojoj advokat postaje Vaš advokat. (VK, 141)

b) Koliko vremena je taksimetar otkucavao?

22.

a) „Šta si to radila, dušo?” upitao sam i počeo da istražujem fioke radnog stola. (VK, 111)

b) Istražujem fioke radnog stola pet minuta / *za pet minuta.

23.

a) Ali čim je podigao glavu, ljudi pritiskaju sirene i počinju da mu dovikuju. (CK, 217)

b) Dovikuju mu pet minuta / *za pet minuta.

24.

a) Vreća mu ovaj put spada pre nego što je počeo da je pridiže. (CK, 499500)

b) Pridiže vreću dva minuta / *za dva minuta.

25 .

a) Trećeg jula 1998. sam ubacio dva kofera i lep-top u ševrolet, počeo da se isparkiravam, stao i ponovo ušao u kuću. (VK, 65)

b) Koliko vremena si se isparkiravao?

U aspektualnim konstrukcijama s početnim faznim glagolima mogu se naći i stanja u dopuni s obzirom na to da ona označavaju radnju koja traje duži ili kraći vremenski period. Budući da se sastoje od nediferenciranog intervala, pravilo je da je kvalitet situacije isti u bilo kom delu tog perioda. Glagoli stanja nekompatibilni su s prilozima kao što su namerno, sporo, brzo, pažljivo itd. jer ne podrazumevaju svesnu realizaciju određene situacije nego samo trajanje u vremenu. 
26.

a) Krenuo sam na sever, pitajući se šta je, tačno, Džon mogao da napiše... jer sam tada počeo da verujem kako je verovatno nešto napisala. (VK, 233)

b) Koliko vremena si verovao?

c) *Namerno / *pažljivo / *sporo verujem kako je verovatno nešto napisala.

27.

a) Mislim da sam tada počeo da se osećam pomalo loše, ali sam bio suviše zamišljen da bih to primetio. (VK, 233)

b) Koliko vremena se osećaš loše?

28.

a) U pitanju je bila Ki. Počela sam da brinem za Ki sve vreme dok je sa njim... sa njima. (VK, 165)

b) *Pažljivo brinem za Ki sve vreme.

29.

a) U stvari, počeo sam da se kajem što nisam otišao pet minuta ranije. (VK, 171)

b) Koliko vremena se kaješ?

Analizom rečeničnih primera iz korpusa može se izvesti zaključak da je najučestaliji tip situacije u komplementu početnog faznog glagola aktivnost koja predstavlja i prototip dopune uz glagole početi/počinjati. U značajno manjem broju nalaze se stanja.

Tabela 3: Kvantitativni prikaz tipova glagolskih situacija u komplementu konstrukcija sa faznim glagolima početi / počinjati

\begin{tabular}{ll} 
TIP GLAGOLSKE SITUACIJE & POČETI / POČINJATI \\
\hline Stanje & 20 \\
Aktivnost & 272
\end{tabular}


Tabela 4: Procentualni prikaz tipova glagolskih situacija u komplementu konstrukcija sa faznim glagolima početi / počinjati

TIP GLAGOLSKE SITUACIJE POČETI / POČINJATI

$\begin{array}{ll}\text { Stanje } & 6,8 \% \\ \text { Aktivnost } & 93,2 \%\end{array}$

Ukupno

$100 \%$

Grafikon 1: Prikaz tipova glagolskih situacija u komplementu konstrukcija sa faznim glagolima početi/počinjati

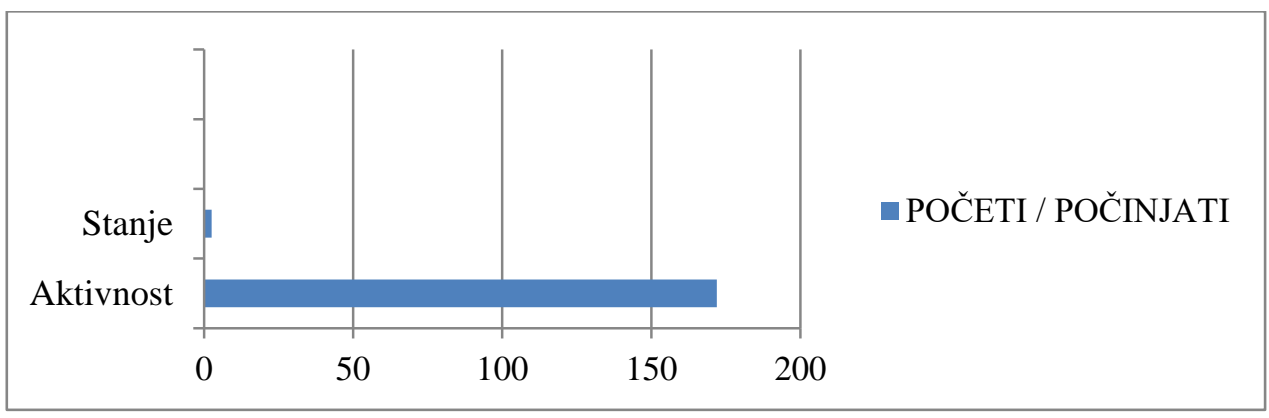

\section{Zaključna razmatranja}

Leksikon srpskog jezika bogat je faznim glagolima, međutim, osnovni parametar za izdvajanje rečenica koje su ušle u sastav prikupljene građe bio je složeni predikat kojeg čini fazni glagoli početi/počinjati i glagol u funkciji dopunske strukture. Teličnost zavisi isključivo od samog glagola, odnosno, telični glagoli su perfektivni, a atelični imperfektivni. Telični perfektivni događaj označava da je krajnja tačka dostignuta i da se događaj ne može produžiti, niti nastaviti. Prema tome, takav događaj ne može da se nađe na poziciji komplementa faznog glagola. U srpskom jeziku povezanost između gramatičkog i leksičkog aspekta rezultira samo jednom mogućom kombinacijom komplementa koja podrazumeva imperfektivni vid sa odsustvom cilja. Kada se ukrsti gramatička kategorija glagolskog vida i leksička kategorija koju predstavlja tip glagolske situacije proizilazi zaključak koji je empirijski potvrđen da u srpskom jeziku imperfektivnost karakteriše aktivnosti i stanja, a perfektivnost odlikuje ostvarenja i dostignuća. S tim u vezi nameće se i tvrdnja da je kontrast između imperfektivnosti i perfektivnosti baziran i na osnovu semantičkog obeležja [cilj]. $\mathrm{Na}$ osnovu analize proučavanih konstrukcija sa početnim faznim glagolima $u$ 
srpskom jeziku i to sa posebnim osvrtom na tip glagolske situacije na poziciji komplementa faznih glagola došlo se do određenih saznanja na osnovu kojih se može izvesti zaključak. Budući da je prisustvo imperfektivnih glagola u komplementu faznih glagola još jednom potvrđeno i u ovom istraživanju, bilo je potrebno izvršiti dodatan uvid u tip glagolske situacije koji podleže imperfektivnom načinu sagledavanja. Primenom sintaksičkih testova, utvrđeno je da se aktivnosti i stanja javljaju u imperfektivnom, a ostvarenja i dostignuća $u$ perfektivnom vidu u srpskom jeziku. Objekat u srpskom jeziku ne utiče na tip glagolske situacije, ali može da utiče na sekundarna obeležja u okviru datog tipa situacije unoseći obeležja poput iterativnosti koje je sekundarno jer ne menja sintaksičko ponašanje lekseme i ne stvara novi tip situacije. U srpskom jeziku, dakle, imperfektivna stanja i aktivnosti predstavljaju validne tipove situacija koji se nalaze na poziciji komplementa faznog glagola.

\section{Z V O R I}

King, Stiven (2003). Crna kuća. Beograd: Editor.

King, Stiven (2010). Vreća kostiju. Beograd: Vulkan izdavaštvo.

\section{I TER A T UR A}

Antonić, Ivana (2000). Aspekatska vrednost predikacije s faznim/modalnim glagolom na primeru rečenice s temporalnom klauzom. Јужнословенски филолог, 56 (1-2): 93- 101.

Binnick, Robert (1991). Time and the Verb. A Guide to Tense and Aspect. Oxford: Oxford University Press.

Comrie, Bernard (1976). Aspect: An Introduction to the Study of Verbal Aspect and Related Problems. Cambridge: Cambridge University Press.

Lazović, Mihaela (2012). Teličnost $i$ glagolski vid u engleskom i rumunskom jeziku u okviru prošlog vremena. Doktorska disertacija. Novi Sad: Filozofski fakultet.

Milivojević, Nataša (2007). Telične partikule u engleskom i perfektivni prefiksi u srpskom jeziku - glagolski vid ili tip glagolske situacije?. Годишњак Филозофског факултета у Новом Саду XXXII (2007): 397-407.

Mrazović, Pavica i Zora Vukadinović (2009). Gramatika srpskog jezika za strance. Sremski Karlovci, Novi Sad: Izdavačka knjižarnica Zorana Stojanovića.

Novakov, Predrag (2005). Glagolski vid i tip glagolske situacije u engleskom i srpskom jeziku. Novi Sad: Futura publikacije.

Novakov, Predrag. (2009). Vendlerova klasifikacija glagola u engleskom i srpskom jeziku. Godišnjak Filozofskog fakulteta 34/1. Novi Sad: Filozofski fakultet. 43-50. 
Novakov, Predrag (2016). Teličnost i perfektivnost u engleskom i srpskom jeziku. U: Jezici i kulture u vremenu i prostoru V (ur. S. Gudurić, M. Stefanović). Novi Sad: Filozofski fakultet. 395-406.

Prćić, Tvrtko (1997). Semantika i pragmatika reči. Novi Sad, Sremski Karlovci: Izdavačka knjižarnica Zorana Stojanovića.

Rothstein, Susan. (2004). Structuring Events: a Study in the Semantics of Lexical Aspect. Malden, USA: Blackwell Publishing Ltd.

Smith, Carlota (1995). The Relation between Aspectual Viewpoint and Situation Type. Aspectual systems in universal grammar and in languages of the world. Paper presented at the Annual Meeting of the Linguistic Society of America. The University of Texas.

Smith, Carlota (1997). The parameter of aspect (second edition). Dordrecht: Kluwer Academic Publishers.

Vendler, Zeno (1967). Linguistics in philosophy. London: Cornell University Press.

Каравесовић, Дејан (2015). Нефинитни глаголски комплементи у енглеском и њихови преводни еквиваленти у српском језику. Докторска дисертација. Крагујевац: Филолошко-уметнички факултет.

Крстић, Маја (2016). Лексички крњи глаголи и њихова употреба у савременом руском и српском језику. Докторска дисертација. Нови Сад: Филозофски факултет.

Мишовић-Луковић, Мирјана (2006). Семантика и прагматика исказа: маркери дискурса у енглеском језику. Београд: Филолошки факултет Универзитета у Београду.

Ружић, Владислава (2006). Допунске реченице у савременом српском језику (I). Зборник Матице српске за филологију и лингвистику, XLIX/1. Нови Сад: Матица српска. 123-219.

Станојевић, Веран и Тијана Ашић (2006). Семантика и прагматика глаголских времена у франиуском језику. Крагујевац: Филолошко-уметнички факултет.

Станојчић, Живојин и Љубомир Поповић (1995). Граматика српскога језика. Београд: Завод за уџбенике и наставна средства. 
Snežana Kljakić

\author{
SITUATION TYPES IN INGRESSIVE PHASE VERB COMPLEMENTS IN \\ SERBIAN
}

\title{
SUMMARY
}

This paper deals with a compound predicate, i.e. a type of predication in the Serbian language which consists of a phase verb and a complement structure verb. The goal of this research was to isolate aspectual constructions with phase verbs početi / počinjati and analyse the semantical and syntactic relation between the constituents within the framework of complex predication in Serbian. An important segment of the analysis was employed to determine all situation types which can be found in phase verb complements. The findings suggest that only two situation types could be found in a complement position. They include states and activities as they are imperfective.

KEYWORDS: phase verbs, aspect, situation type, Aktionsart, telicity, coercion, Serbian.

Dr Snežana Kljakić Filozofski fakultet, Univerzitet u Novom Sadu Srbija snezana.kljakic@gmail.com 
